This PDF is a selection from a published volume from the National Bureau of Economic Research

Volume Title: Governance, Regulation, and Privatization in the Asia-Pacific Region, NBER East Asia Seminar on Economics, Volume 12

Volume Author/Editor: Takatoshi Ito and Anne O. Krueger, editors

Volume Publisher: University of Chicago Press

Volume ISBN: 0-226-38679-1

Volume URL: http://www.nber.org/books/ito_04-1

Conference Date: June 28-30, 2001

Publication Date: January 2004

Title: The Korean Economic Crisis and Corporate Governance System

Author: Sung Wook Joh

URL: http://www.nber.org/chapters/c10187 


\title{
The Korean Economic Crisis and Corporate Governance System
}

\author{
Sung Wook Joh
}

\subsection{Introduction}

After Korea's being touted as one of Asia's economic tigers, the country's 1997 economic collapse shocked many people. Many argued that after other Asian country crises, the massive creditor and investor flight from the Korean currency market caused Korea's high-debt economy to collapse. However, this argument ignores both Korea's low corporate profitability over the last decade, and the fundamental causes of the financial sector's weakness. Following a discussion on how high debt-equity ratios and low profitability helped cause the 1997 Korea economic crisis, I will examine their determinants, and how poor corporate governance allowed such low profitability to occur for so long. Finally, I will discuss recent reforms and their preliminary results.

Advocates of the currency-flight view point to Korea's high-debt economy over the past decade to support their argument. Compared to other countries, Korea's debt-equity ratio was very high. Furthermore, high debtequity ratios in Korea have been the norm for many years. In the currencyflight view, although these high debt-equity ratios spurred high growth, they also left Korean firms vulnerable to fickle creditors and investors. When other Asian economies such as Thailand and Indonesia collapsed, creditors and investors pulled their money out of Korean firms. The

Sung Wook Joh is professor in the business school at Korea University.

I am grateful to the participants at the 12th Annual NBER seminar on the East Asian Economics for their helpful comments on the earlier version of the paper. I am especially grateful to Anne Krueger, Mario Lamberte, Philip Williams, and an anonymous referee for their detailed and helpful comments. 
ensuing liquidity crisis forced many firms to default on their loans. Thus, many firms failed, and the Korean economy collapsed.

Criticism of the above argument includes (1) the absence of high profits, (2) the many firm failures before the collapse of other Asian economies, and (3) the argument's dependence on creditor and investor irrationality. With high debt-equity ratios, Korean firms were expected to yield high profits on their equity. However, the average rate of return on equity was often lower than the prevailing interest rates for loans (Joh 2003), and the return on capital had been lower than the opportunity cost. Krueger and Yoo (2001) showed that the rate of return on assets (ROA) of the Korean manufacturing sector has been lower than that of other countries such as Japan, Germany, the United States, and Taiwan. So, on average, the capital used in the corporate sector was wasted on unprofitable projects.

Korea's weak corporate governance allowed this low profitability to continue for almost ten years before the crisis. Many firms, including six of the thirty largest conglomerates, failed before the collapse of other Asian economies simply because their low profits fell short of their required loan payments (Joh 2002). The failure of many large firms severely weakened financial institutions. Rationally concerned about their investments and loans, foreign investors sold their Korean stocks, and foreign banks demanded repayment of the short-term loans given to Korean financial institutions rather than rolling them over to the following year, which had been the usual practice. Foreign banks and investors exacerbated the crisis; they did not cause it.

\subsection{Crisis and Corporate-Sector Problems}

High debt-equity ratios and low firm performance helped trigger failures of large chaebols even before the 1997 economic crisis. In this section, we review the causes of the corporate-sector problems.

\subsubsection{High Corporate Debt}

As figure 5.1 shows, the average debt-equity ratio of Korean firms has been very high for a long time and did not rise before the crisis. In 1997, Korean firms' average debt-equity ratio was higher than those of other countries' (Korea, 396 percent; United States, 154 percent; Japan, 193 percent; Taiwan, 86 percent. $^{1}$

When six of the thirty largest chaebols (business groups) went bankrupt before the currency crisis, it triggered a cascade of nonperforming loans. Starting with the default by Hanbo (ranked fourteenth) in January 1997 well before the Asian crisis, a series of large chaebol defaults raised suspicion regarding conglomerates' survival and the fundamental soundness of 


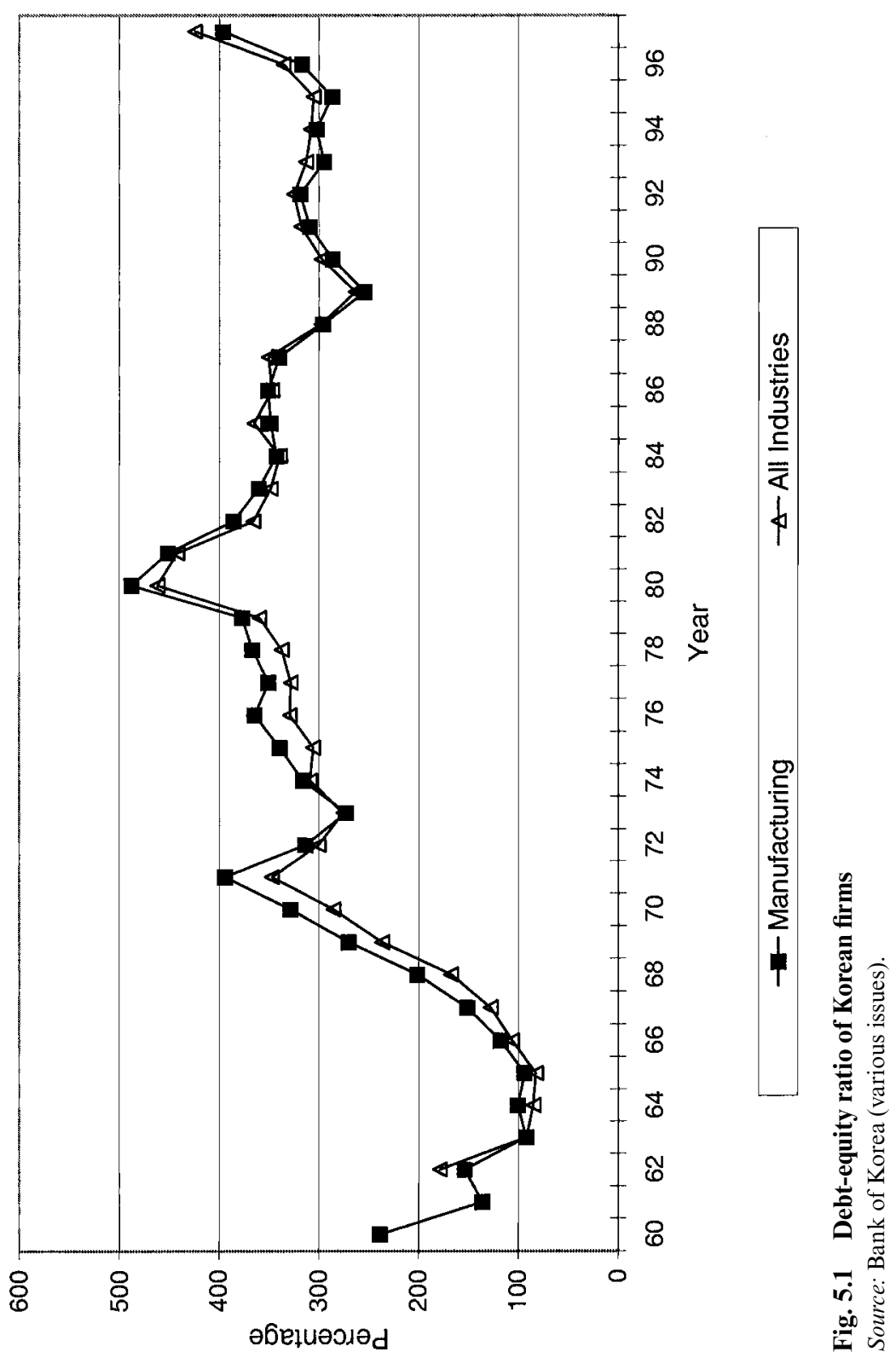


Table 5.1

Six Bankrupt Conglomerates among the Thirty Largest Chaebol (all defaulted in 1997)

\begin{tabular}{lcccccc}
\hline & Hanbo & Sammi & Jinro & KIA & Haitai & New-Core \\
\hline Default date & 23 January & 19 March & 21 April & 15 July & 1 November & 4 November \\
Ranking & 14 th & 25 th & 19 th & 8 th & 24th & 28th \\
Debt (trillions of won) & 4.42 & 2.43 & 3.23 & 9.57 & 2.52 & 1.85 \\
Debt-equity ratio & $648 \%$ & $3,333 \%$ & $4,836 \%$ & $522 \%$ & $669 \%$ & $1,253 \%$ \\
\hline
\end{tabular}

Sources: Default date and ranking are from Shin and Hahm (1998). Debt size and debt-equity ratio are from Korea Fair Trade Commission (1999).

the corporate sector. The total debt of these bankrupt conglomerates alone amounted to 24.02 trillion won (see table 5.1), 35.5 percent and 5.3 percent of the government budget and gross national product (GNP), respectively, in 1997. Although the money for bailout would be smaller than the size of debt, large debt of the failed chaebols in 1997 implied that bailout would cost more than earlier bailouts. For example, during the financial crisis in the middle of 1980s, the Bank of Korea provided six commercial banks with 1.7 trillion won between 1985 and 1987 to rescue many debt-ridden firms that became insolvent (see Joh 2001). Because the debt of the chaebol became too large for the economy, and other firms were doing so poorly that they could not easily acquire the firms with such high levels of debt, it was extremely difficult for the government to rescue the firms in trouble in 1997.

Due to their size and importance in subcontracting, ${ }^{2}$ the failure of these chaebols had a devastating impact on the economy, leading to a series of bankruptcies. When we consider bankruptcy of subcontractors, the impact of the failure of these conglomerates would be too large for the government to handle. Table 5.2 shows the rapid increase in the ratio of nonperforming loans from 1997 to $1998 .^{3}$

\section{Causes of High Debt-Equity Ratio}

During the early high-growth period, the government provided large firms with capital at low interest rates. Because large firms were more likely to receive government-subsidized capital and the government's implicit guarantees, firms had an incentive to increase their size by using crossholdings and cross-debt guarantees. Moreover, creditors were not provid-

2. Chung and Yang (1992) report that the shares of the top five and top thirty chaebol in GNP were 9.2 percent and 16.3 percent, respectively. The Korea Economic Research Institute reports that in 1995 the shares of the top four and top thirty were 9.2 percent and 16.2 percent, respectively.

3. Many criticize that these official numbers underestimated the true size of nonperforming loans. Some estimate that nonperforming loans reached somewhere between 200 and 300 trillion won. 
Nonperforming Loans (end of period)

\begin{tabular}{lccccc}
\hline & $\begin{array}{c}\text { December } \\
1997\end{array}$ & $\begin{array}{c}\text { March } \\
1998\end{array}$ & $\begin{array}{c}\text { June } \\
1998\end{array}$ & $\begin{array}{c}\text { September } \\
1998\end{array}$ & $\begin{array}{c}\text { December } \\
1998\end{array}$ \\
\hline Precautionary loans & 42.8 & 57.7 & 72.5 & n.a & n.a. \\
Substandard loans or below (A) & 43.6 & 59.6 & 63.5 & 64.0 & 60.2 \\
$\quad$ Bank & 31.6 & 38.8 & 40.0 & 35.0 & 33.6 \\
NBFI & 12.0 & 20.8 & 23.5 & 29.0 & 26.6 \\
Total loan (B) & 647.4 & 668.7 & 624.8 & 614.3 & 576.5 \\
A/B (\%) & 6.7 & 8.9 & 10.2 & 10.4 & 10.5 \\
\hline
\end{tabular}

Sources: Financial Supervisory Commission (various press releases).

Notes: Precautionary loans were overdue for more than three months, and substandard loans were overdue for more than six months. Loan classification has changed since 1999. Amounts are in trillions of won.

ing a monitoring role to failing firms. Rather, banks continued to provide loans to failing firms. These factors helped cause high debt-equity ratios.

Government-Provided Incentives and Bailouts for Large Firms. Since the 1960s, past Korean governments have mobilized and allocated scarce capital to firms and industries (such as light-export-oriented industries and heavy and chemical industries) based on an assessment of their contribution to the nation's industrialization and modernization. The government used a compliance mechanism that effectively guided the behavior of major businesses (Jones and SaKong 1980). Through nationalized banks, the government provided targeted firms with capital at lower interest rates than time deposit rates or inflation rates until the beginning of the 1980s. Financial institutions simply implemented the government decisions and made no independent decisions. Lee (1992) argued that the Korean government operated an internal capital market and channeled subsidized credit to carefully targeted firms and industries.

When the government subsidized debt during the high-growth period, it was a rational decision for firms to increase their levels of debt. As table 5.3 shows, until 1981 borrowing money from the national investment fund, or borrowing for export, was lucrative because the borrowing interest rate was lower than the interest rate on one-year time deposits or the inflation rate. After 1981, interest rates on bank loans became greater than interest rates on savings in time deposits. This was possible because the earlier Korean government nationalized and owned the banks and regulated the interest rates. It also practically dictated the credit allocation. This credit policy affeted the corporate sector: firms formed a large business group to expropriate cheap loans. Creditors in credit allocation decisions favored business groups because subsidiaries could provide debt payment guarantees and the government implicitly guaranteed them when they were in financial distress.

With subsidized debt, firms were encouraged to invest in labor-intensive 
Table 5.3

Interest Rates, 1964-1981

\begin{tabular}{lcccccc}
\hline & & & \multicolumn{3}{c}{ Bank Loans } & \\
\cline { 4 - 5 } Year & Inflation (CPI) & Time Deposit & General & NIF & Export & Curb Market \\
\hline 1964 & - & 15.0 & 16.0 & - & 8.0 & 61.8 \\
1965 & - & 30.0 & 26.0 & - & 6.5 & 58.9 \\
1966 & 11.2 & 30.0 & 26.0 & - & 6.0 & 58.7 \\
1967 & 10.9 & 30.0 & 26.0 & - & 6.0 & 56.7 \\
1968 & 10.8 & 26.0 & 25.2 & - & 6.0 & 56.0 \\
1969 & 12.3 & 24.0 & 24.0 & - & 6.0 & 51.4 \\
1970 & 15.9 & 22.8 & 24.0 & - & 6.0 & 50.2 \\
1971 & 13.5 & 22.0 & 22.0 & - & 6.0 & 46.4 \\
1972 & 11.7 & 15.0 & 15.5 & - & 6.0 & 39.0 \\
1973 & 3.1 & 12.6 & 15.5 & - & 7.0 & 33.2 \\
1974 & 24.3 & 15.0 & 15.5 & 12.0 & 9.0 & 40.6 \\
1975 & 25.3 & 15.0 & 15.5 & 12.0 & 9.0 & 47.9 \\
1976 & 15.3 & 15.6 & 18.0 & 14.0 & 8.0 & 40.5 \\
1977 & 10.1 & 15.8 & 16.0 & 14.0 & 8.0 & 38.1 \\
1978 & 14.4 & 16.9 & 19.0 & 16.0 & 9.0 & 41.7 \\
1979 & 18.3 & 14.4 & 19.0 & 16.0 & 9.0 & 42.4 \\
1980 & 28.7 & 19.5 & 20.0 & 19.5 & 15.0 & 44.9 \\
1981 & 21.3 & 16.2 & 17.0 & 17.5 & 15.0 & 35.3 \\
\hline
\end{tabular}

Sources: Cho and Kim (1997; original source, Bank of Korea, Economic Statistics Yearbook, various issues).

Notes: $\mathrm{CPI}=$ consumer price index; NIF $=$ National Investment Fund. Dash indicates data are not available.

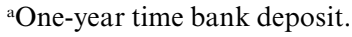

exporting industries, or the heavy and chemical industry, ${ }^{4}$ in the 1960 s and 1970 s, respectively. The return from investment in these industries resulted partly from lower capital costs and/or lower corporate income taxes and the like. ${ }^{5}$ Therefore, at the individual level, each firm had an incentive to invest in these industries, and may have made a rational choice of investment, other things being equal. Consequently, investment in these industries in the aggregate may have exceeded the socially optimal level as resources shifted from other, more socially profitable industries.

Moreover, with huge debt, firms were vulnerable to drops in demand and macroeconomic shocks. Each time many large firms faced financial distress, the government intervened and rescued them. ${ }^{6}$ During the debt crisis

4. These industries include power-generating equipment, cars, engines, heavy electric equipment, telephone-switching systems, refined copper, etc.

5. Kim (1997) reports that President Park Chung Hee held monthly cabinet meetings that decided policy measures to facilitate exports. Kim also reports that exporting firms received credits at a lower interest rate and paid corporate income tax at 50 percent of the usual corporate income tax rate.

6. See Joh (2001) for more discussion on this issue. 
of 1972, the government froze their debts and gave bailout loans ${ }^{7}$ to firms in financial distress. From 1979 to 1983, firms again suffered from overinvestment and depression following the second oil shock (Lee 1995). To deal with insolvency problems associated with excessive capacity, the government gave financial subsidies and consolidated firms to create more concentrated markets. In the 1980s, the government adopted some liberal procompetition policies, privatizing commercial banks during 1981-1983, and reducing the gap in interest rates between industrial policy loans and general loans. During 1984-1988, many debt-ridden firms became insolvent, only to have the government intervene yet again. ${ }^{8}$ By providing creditor banks with special 3 to 6 percent interest rate loans (the general bank loan rate was about 12 percent; see Lee 1995), the government allowed these banks to write off bad debts, extend debt maturities, and replace existing debt with longer-term debt at a lower rate. ${ }^{9}$ In short, the government had repeatedly given large firms preferential subsidies and bailed them out during times of financial distress.

Firms Inflate Size with Cross-Holdings and Cross-Debt Guarantees. Large firms received both low-cost capital for undertaking large projects and implicit guarantees from the government. Thus, firms had incentives to exaggerate their true size and performance. This was particularly easy for business group firms that engaged in intragroup transactions and interlocking ownership. ${ }^{10}$ For example, through interlocking ownership, a firm A invests its assets in an affiliated firm B. Through double-counting of these investments, the sum of the assets of $A$ and $B$ can exceed the total assets of the group.

Chaebols also can borrow more money through cross-debt payment guarantees. On average, a few large and better-performing firms in a chaebol typically guaranteed 80 percent of the chaebol firms' total debt. Moreover, chaebols with higher debt payment guarantees managed to borrow more money, resulting in higher debt-to-equity ratios at the group level (Lee 1998). Using debt payment guarantees, even poorly operating subsidies managed to borrow money. The total debt payment guarantees often far exceeded their total equity, raising doubts on their validity (see table 5.4).

Loans to Failing Firms. Banks continued lending to high debt-equity firms, as table 5.5 shows. The largest thirty chaebols had very high debt-equity

7. For more of the 1972 government emergency measure, see Cho and Kim (1997).

8. The government revised its tax exemption law to facilitate the insolvency procedure in December 1985.

9. See Cho and Kim (1997). In total, acquiring firms and consolidating firms received subsidies worth 7.28 trillion won (Lee 1995).

10. At least 60 percent of firms subject to external auditing report that they have legally affiliated firms. See Joh (2003). 
Table 5.4

Debt Payment Guarantees of the Thirty Largest Chaebol (trillions of won)

\begin{tabular}{|c|c|c|c|c|c|c|}
\hline \multirow[b]{3}{*}{ Year } & \multirow{3}{*}{$\begin{array}{l}\text { Equity } \\
\text { (A) }\end{array}$} & \multicolumn{3}{|c|}{ Amount of Debt Payment Guarantee } & \multirow{2}{*}{\multicolumn{2}{|c|}{ Ratio (\%) }} \\
\hline & & Restriction & No Restriction & & & \\
\hline & & (B) & (C) & $(B+C)$ & $\mathrm{B} / \mathrm{A}$ & $(\mathrm{B}+\mathrm{C}) / \mathrm{A}$ \\
\hline 1993 & 3.52 & 12.06 & 4.49 & 16.55 & 342.4 & 469.8 \\
\hline 1994 & 4.28 & 7.25 & 3.82 & 11.07 & 169.3 & 258.1 \\
\hline 1995 & 5.07 & 4.83 & 3.38 & 8.21 & 95.2 & 161.9 \\
\hline 1996 & 6.29 & 3.52 & 3.23 & 6.75 & 55.9 & 107.3 \\
\hline 1997 & 7.04 & 3.36 & 3.13 & 6.49 & 47.7 & 92.2 \\
\hline
\end{tabular}

Source: Korea Fair Trade Commission (various dates).

Table 5.5

High Debt-Equity Ratios and Accounting Profitability of Thirty Large Chaebol

\begin{tabular}{lcccccc}
\hline & 1995 & 1996 & 1997 & 1998 & 1999 & 2000 \\
\hline Average debt-equity ratio & 347.5 & 386.5 & 519.0 & 369.1 & 306.6 & 218.7 \\
Groups with debt-equity $\geq 1,000 \%$ & 3 & 3 & 4 & 2 & 2 & 2 \\
Groups with negative equity & 0 & 0 & 2 & 8 & 5 & 3 \\
Groups with loss & 13 & 12 & 18 & n.a. & n.a. & n.a. \\
\hline
\end{tabular}

Sources: Korea Fair Trade Commission (various dates) and Choi (1996, 1997, 1998).

Notes: n.a. = not available. Chaebol with negative equity were not included in calculating the average debt-equity ratio.

ratios (348 percent in 1995, 519 percent in 1997), some exceeding 1,000 percent. Moreover, before the crisis occurred, more than 40 percent of the largest thirty chaebols experienced losses. For example, thirteen out of thirty chaebols exhibited losses in 1995. Beginning in 1997, some chaebols showed that the accumulated losses eroded their paid-in capital completely, resulting in negative equity. However, these chaebols managed to maintain their debt levels, or borrowed more, resulting in a higher level of debt-to-equity ratios. The continuing flow of capital to large conglomerate firms suggests that financial institutions were not making lending decisions based on monitoring chaebol finances.

\subsubsection{Low Corporate Firm Performance}

With high debt-equity ratios, Korean firms were expected to yield high performance on their equity. When highly profitable firms borrow money to exploit their investment and growth opportunities, a high debt level might not be a serious problem. However, as figure 5.2 shows, the average rate of return on equity was often lower than the prevailing interest rates for loans. On average, the return on capital had been lower than its 


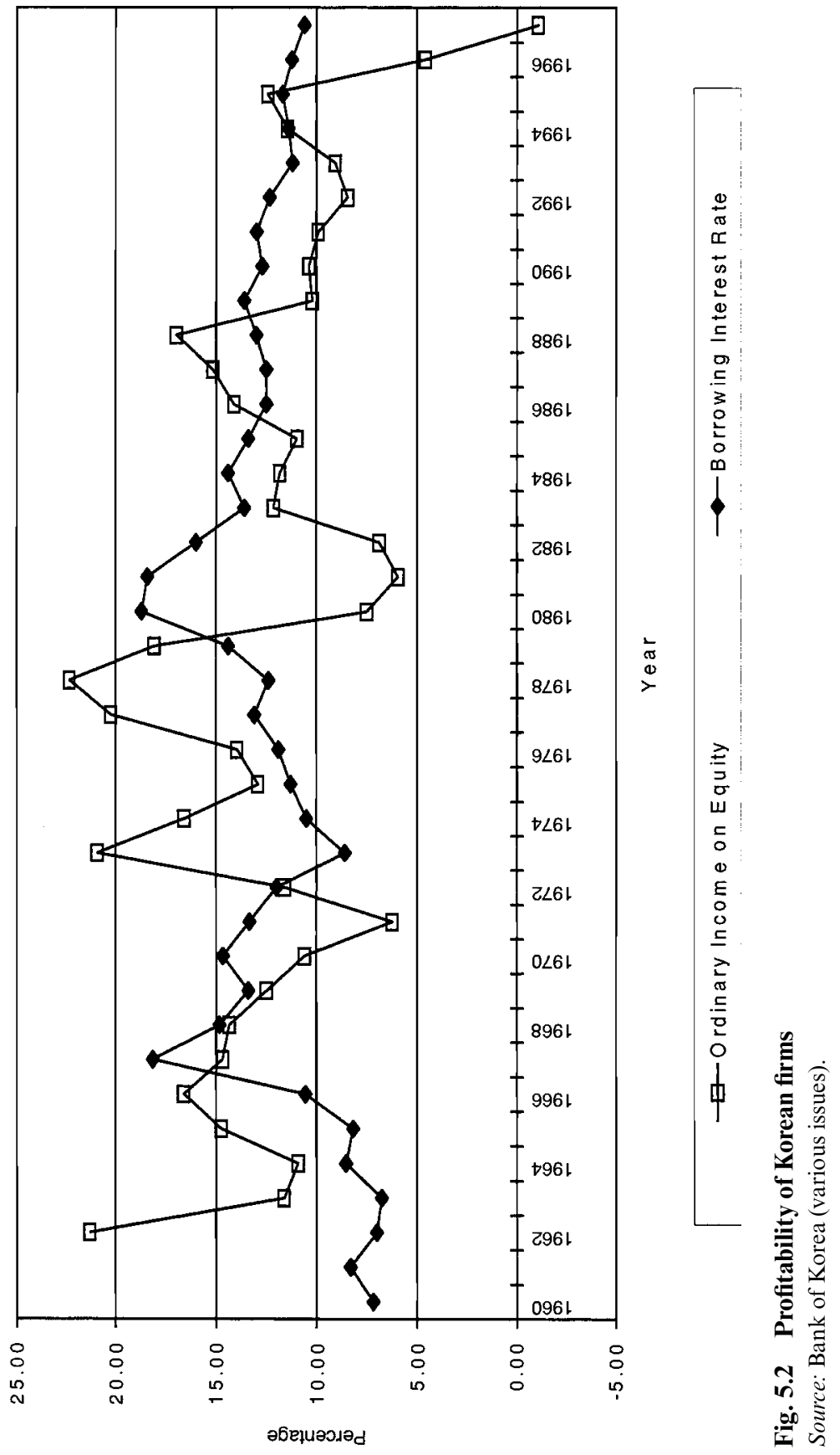


opportunity cost for almost ten years before the crisis. So, the capital was, on average, wasted on unprofitable projects.

Moreover, the return in the stock market also shows that shareholders on average did not receive high returns either. Shareholders received very small dividends as firms did not make much profit, and on average they did not make capital gains either. The monthly Korean stock price index in figure 5.3 shows large ups and downs in the return on stocks. For almost five years after the stock market opened, the stock price index hardly changed. Starting in the middle of the 1980s, the stock price increased fast and reached its peak in 1989. However, in the 1990s the index was below the peak in the 1980s, except for a few observations. In addition, after the peak of October 1994 the average stock index already had started to decline before the economic crisis.

From these two figures, it is clear that firm performance was weak and shareholders did not receive high returns. Why was the performance of the corporate sector so low? There are several factors to examine. First, large, poorly performing firms did not exit the market; and second, controlling shareholders did not increase firm value. Rather, they diverted firm resources.

To examine the causes of the low performance of Korean firms, I analyze panel data on publicly traded firms' ownership and financial data compiled by National Information Credit Evaluation, Inc. (NICE). Due to ownership data availability, I examine firm data from 1993 to 1997. For the analysis of Korean data, accounting profitability rather than stock market-based performance is likely a better performance measure for a couple of reasons. First, developing countries show stock market inefficiency, so stock prices in Korea are not likely to reflect all available information. Second, a firm's accounting profitability is more directly related to its financial survivability than stock market value is (Mossman et al. 1998). Many studies used accounting measures to predict bankruptcy (Altman 1968, Takahashi, Kurokawa, and Watase 1984) or financial distress (Hoshi, Kashyap, and Sharfstein 1991).

After excluding financial institutions and state-controlled firms from the analysis, the data set includes 4,702 observations between 1993 and 1997. I examine whether owners with more control rights than ownership rights expropriated firm resources before the crisis. As Jensen and Meckling (1976) argue, a controlling shareholder has an incentive to expropriate firm resources when his or her control rights exceed ownership rights because his or her private benefits exceed their costs. Concentrated ownership means less discrepancy of interests under the assumption that the control level is very high. This assumption is likely to hold because the control and influence of controlling shareholders is very high in Korea. Korea suffers from a poor corporate governance system, as the legal institutional environment does not protect minority shareholders and the controlling 


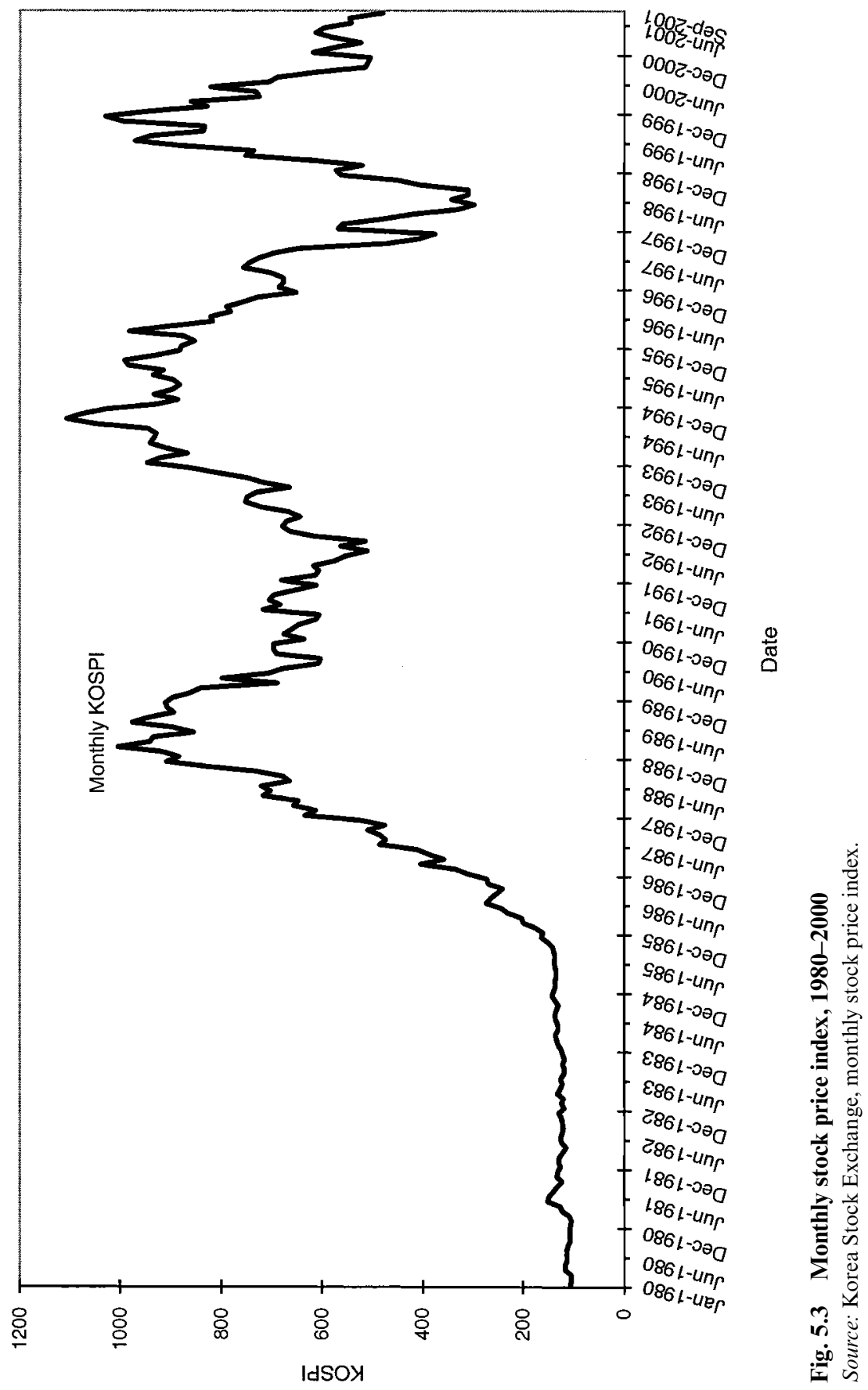


Table 5.6

Determinants of Profitability among Publicly Traded Firms

Ordinary Income/Sales

(1)

(2)

\begin{tabular}{lcc}
\hline Ownership & 0.0505 & \\
& $(9.84)$ & \\
Control and ownership-rights difference & & -0.0205 \\
& & $(-3.99)$ \\
Debt ratio & -0.0272 & -0.0257 \\
& $(-7.40)$ & $(-6.94)$ \\
Chaebol dummy & -1.3473 & -1.5620 \\
& $(-3.52)$ & $(-3.95)$ \\
Log (asset) & 0.1408 & -0.3097 \\
& $(0.95)$ & $(-2.16)$ \\
R\&D/sales & -0.0605 & -0.0766 \\
& $(-1.20)$ & $(-1.50)$ \\
Export/sales & 0.0126 & 0.0120 \\
& $(2.14)$ & $(2.01)$ \\
Advertisement/sales & -0.0281 & -0.0048 \\
& $(-0.38)$ & $(-0.06)$ \\
Market share & 0.0675 & 0.0794 \\
& $(3.90)$ & $(4.56)$ \\
Industry and year dummies & Included & Included \\
No. of observations & 4,702 & 4,702 \\
Adjusted $R^{2}$ & 0.3673 & 0.3560
\end{tabular}

Notes: The regression tests the determinants of accounting profitability based on listed firms between 1993 and 1997. Ownership measures the controlling shareholder and his or her family member's ownership excluding the intragroup shareholding. Control and ownershiprights difference is measured as the sum of all institutional and intragroup ownership minus controlling shareholder and his or her family member's ownership. An industry dummy is assigned for each five-digit Korean standard industrial classification code. The chaebol dummy takes a value of 1 when a firm belongs to one of the largest seventy chaebol. Numbers in parentheses are $t$-values controlling for heteroskedasticity.

shareholders' position is secured. Using ownership that is the stake of the largest shareholder and his or her family members, the empirical result is presented in column (1) in table 5.6. However, ownership is not a direct measure of the discrepancy between control rights and ownership rights unless controlling shareholders' control is more or less similar. To incorporate the referee's concern, I also use the difference between control rights and ownership rights in the analysis. I include the results in column (2) in table 5.6.

Controlling firm size, capital structure, and firm- and industry-specific characteristics, ${ }^{11}$ I found that firms with high controlling shareholder ownership outperformed those with low controlling shareholder ownership, as the first column shows. In the second column, firms with high discrepancy between control rights and ownership rights show lower profitability. Like-

11. For a brief summary of how these variables affect firm performance, see Martin (1993). 
wise, independent firms outperformed chaebol. The results are consistent with the argument that controlling shareholders with a large disparity between control and ownership rights pursue their own private interests at the expense of other shareholders. For more on this, see Jensen and Meckling (1976) and Joh (2003).

\section{Cause of Low Firm Performance}

The above results show that controlling shareholders have expropriated small shareholders, lowering corporate performance. In other words, Korean firms' low profits persisted because the corporate governance system did not induce firm management to maximize firm value.

According to Shleifer and Vishny (1997), corporate governance defines the ways in which the suppliers of finance to corporations are assured of getting a return on their investment in a firm. By defining firm rules, incentives, and goals, the management, capital suppliers, and other stakeholders affect the mechanisms by which capital and resources are allocated, profits are distributed, and performance is monitored. In a corporate governance system that operates for the benefit of all shareholders, ${ }^{12}$ management pursues maximization of firm value.

This section examines the factors that contribute to poor corporate governance systems. In particular, we examine factors including (1) no credible exit threat, (2) lack of financial-institution monitoring, (3) few legal rights or types of protection for minority shareholders, (4) a negligent board of directors, and (5) inadequate financial information.

No Credible Exit Threat. Ideally, the market continuously revolutionizes from within, incessantly destroying the old firms and creating new ones, according to Schumpeter (1952). As weak firms fail, new, strong firms will replace them and employ people who lost jobs. Resources are released and shifted from the dying factories and firms to entering producers. In Korea, this "creative destruction" process was so weak for large firms that resources were not efficiently allocated.

Using the annual census data, Joh (2000) showed that the Korean manufacturing sector has high turnover (see table 5.7). The annual output by new and dying plants over total economy output was high, 4.1 percent and 5.4 percent, respectively. Between 1990 and 1998, the output ratios of entering and exiting plants, including switching plants, exceed 12.0 percent and 16.9 percent of total output, respectively. The entering and exiting plants over total plants were even higher, reaching 14.4 percent and 17.7 percent, respectively. When switching plants were included, the ratio jumped to 24 percent and 32 percent. These turnover rates are higher than

12. With financial market liberalization and globalization, shareholders' interests become most important. 
Table 5.7

Output by Plants with Different Turnover Status, 1990-1998 (\%)

\begin{tabular}{lccccc}
\hline & Continuing Plants & New Plants & Switch-Ins & Dying Plants & Switch-Outs \\
\hline 1990 & & & & 3.7 & 18.8 \\
1991 & 69.3 & 4.3 & 11.7 & 4.4 & 10.3 \\
1992 & 70.2 & 3.8 & 5 & 7.4 & 13.6 \\
1993 & 70.9 & 6.4 & 9.5 & 4.9 & 8.3 \\
1994 & 75.5 & 3.1 & 5.1 & 5.7 & 10.6 \\
1995 & 74.7 & 4.0 & 6.9 & 5.5 & 8.9 \\
1996 & 74.0 & 3.8 & 6.1 & 5.1 & 11 \\
1997 & 71.9 & 3.7 & 7.4 & 6.2 & 10.8 \\
1998 & & 3.9 & 11.4 & n.a. & n.a. \\
Mean & 72.4 & 4.1 & 7.9 & 5.4 & 11.5 \\
\hline
\end{tabular}

Source: Joh (2000).

Notes: n.a. $=$ not applicable. The mean is a simple average over time.

those in most countries. The exit rates measured by percentage of producers for the United States, the United Kingdom, Germany, and Canada are 7.0 percent, 11.5 percent, 4.6 percent, and 4.8 percent, respectively (Joh 2000).

However, turnover rate varies depending on the plant size. For larger plants, turnover is much lower. While small plants exit the market when they fail, large plants often do not. Table 5.8 summarizes the effects of size on turnover. Panel A shows the effect of number of employees, panel B shows effects of asset size, and panel $\mathrm{C}$ shows the effects of capital equipment ratio on turnover. All panels show very similar results. Birth and death rates are lower in the group of plants with the most employees, greatest assets, or greatest capital ratio. These findings imply that the exit threat for large firms was not as effective as that for small plants. Without a credible threat to firm survival, managers of large firms had less incentive to improve firm performance. In addition, large, failing firms continued to operate, taking away resources from profitable firms.

Large firms faced a weak exit threat for three reasons. The first of these was lengthy bankruptcy proceedings. There were three formal bankruptcy procedures: liquidation, composition, and corporate reorganization (similar to Chapter 11 of the U.S. bankruptcy code). However, these formal insolvency procedures for large firms were rarely used in Korea until 1997. Lengthy proceedings, often lasting several years, invited strategic and opportunistic debtor behavior, thus reducing the attractiveness of bankruptcy alternatives for creditors (see table 5.7). Although more than 17,000 cases of insolvency were reported in 1997, only 490 were filed before the court. Of these, only thirty-eight liquidations were filed (Organization for Economic Cooperation and Development [OECD] 1998). Moreover, the 
Table 5.8

Output Ratios by Plant Turnover Status When Size is Measured through Employees, Assets, and Capital Equipment, 1990-1998 (\%)

\begin{tabular}{lccccc}
\hline & Continuing & New Plants & Switch-Ins & Dying Plants & Switch-Outs \\
\hline \multicolumn{5}{c}{ A. Number of Employees } \\
Top 20\% & 76.9 & 2.5 & 7.3 & 3.3 & 10.0 \\
$20-40 \%$ & 73.0 & 5.2 & 6.7 & 6.8 & 8.3 \\
$40-60 \%$ & 67.3 & 8.3 & 7.0 & 8.9 & 8.5 \\
$60-80 \%$ & 57.5 & 11.5 & 8.2 & 12.6 & 10.2 \\
$80-100 \%$ & 45.8 & 17.2 & 8.2 & 20.0 & 8.8 \\
& \multicolumn{5}{c}{ B. Asset Size } \\
Top 20\% & 77.1 & 2.6 & 7.3 & 3.2 & \\
$20-40 \%$ & 72.6 & 4.8 & 6.8 & 6.6 & 9.8 \\
$40-60 \%$ & 69.2 & 6.8 & 6.7 & 8.8 & 9.2 \\
$60-80 \%$ & 56.8 & 10.8 & 8.7 & 13.3 & 10.4 \\
$80-100 \%$ & 46.2 & 17.9 & 7.5 & 18.8 & 9.6 \\
& \multicolumn{5}{c}{ C. Capital Equipment Ratio } \\
Top 20\% & 76.8 & 3.1 & 7.5 & 3.2 & \\
$20-40 \%$ & 74.6 & 3.6 & 7.2 & 5.0 & 9.4 \\
$40-60 \%$ & 75.0 & 3.5 & 6.5 & 5.5 & 9.6 \\
$60-80 \%$ & 70.5 & 5.0 & 6.5 & 7.8 & 10.2 \\
$80-100 \%$ & 54.5 & 11.5 & 8.6 & 13.3 & 12.2 \\
\hline
\end{tabular}

Source: Joh (2000).

Table 5.9

Number of Cases and Duration of Bankruptcy Proceedings (1993-1995)

\begin{tabular}{lrrrrrrrr}
\hline & \multicolumn{7}{c}{ Number of Years } & \\
\cline { 2 - 7 } & $\leq 3$ & $4-5$ & $6-7$ & $8-10$ & $11-15$ & $16-20$ & Total \\
\hline Successful turnaround, conclusion & 1 & 1 & 2 & 6 & 7 & 1 & 18 \\
Failure, termination & 17 & 12 & 10 & 8 & 5 & 0 & 52 \\
\hline
\end{tabular}

Source: Court Administration Agency, recited from Koo (1998).

law allowed firms that owed less than 250 billion won to use a settlement procedure in which the court played a rather minor role while the debtor retained possession of its estate. Composition offered few guarantees to creditors, and 65.7 percent of insolvent firms ( 322 out of 490 cases) applied for this settlement procedure. The remaining firms applied for corporate reorganization, but their financial conditions often had deteriorated too far to restructure successfully. Koo (1998) showed that the average debtequity ratio of these firms was 1,200 percent. See table 5.9 for a summary of the number of cases and duration of the proceedings.

The second cause of the weak exit threat companies faced was the underdeveloped corporate control market. Government regulations on mergers and acquisitions (M\&As) and ownership structure also weakened the 
Table 5.10

In-Group Ownership Trends of the Thirty Largest Chaebol (\%)

\begin{tabular}{llllllllll}
\hline & 1989 & 1990 & 1991 & 1992 & 1993 & 1994 & 1995 & 1996 & 1997 \\
\hline 30 largest chaebol & 31.5 & 31.7 & 33.0 & 33.5 & 33.1 & 33.0 & 32.8 & 33.8 & 34.5 \\
5 largest chaebol & 35.7 & 36.3 & 38.4 & 38.6 & 37.2 & 35.0 & n.a. & n.a. & 36.6 \\
\hline
\end{tabular}

Source: Korea Fair Trade Commission (1999).

Note: n.a. $=$ not available.

exit mechanism. Until recently, hostile mergers and acquisitions were not allowed, and even friendly M\&As were limited to small firms. ${ }^{13}$ Any M\&A by foreigners involving over two trillion won in assets required government approval. The mandatory-tender-offer system required investors who bought over 25 percent of a firm's shares to publicly purchase over 50 percent of the shares. In addition, the ownership structure of chaebol, with large interlocking ownership by affiliated firms as shown in table 5.10, obstructed takeovers by outside investors. Controlling shareholders with less than 10 percent direct ownership have control through interlocking ownership by other firms in the same chaebol group. Therefore, corporate raiders needed to buy the sum of the incumbent controlling owners' shares, the interlocking firms' shares, and one more share.

Finally, government support for weak, large firms was an additional cause of the weak exit threat. Before the crisis, large firms hardly faced any exit threats because of the government's implicit guarantee. ${ }^{14}$ As discussed earlier, the government had repeatedly rescued many failing chaebol. Because of the debt payment guarantees, poorly performing subsidiaries can cause financial distress for high-performing subsidiaries. So the failure of a few subsidiaries in a large conglomerate can cause a chain reaction of failures and devastate the economy. Partially due to its impacts on employment and on the overall economy, the government arranged for some banks to lend more money to these failing firms. This government behavior led to the belief that chaebols were "too big to fail."

Lack of Financial-Institution Monitoring. Financial institutions as creditors should monitor their borrowing firms to insure their lending. However, financial institutions in Korea have not provided adequate monitoring, even though Korean firms rely heavily on debt for their financing. There are at least two reasons. Although once-nationalized commercial banks were privatized in the 1980s, the legacy of government control remained through interest rate regulation, credit policies, and governmentappointed top executives. As a result, banks did not develop suitable credit

13. In May 1998, six months after the 1997 crisis, the Korean government removed all restrictions on M\&A activities.

14. Kukjae's failure in 1984 was a politically motivated exception. 
evaluation and risk management techniques to make informed loan decisions. Banks did not have an incentive to monitor or discipline managers. Often, they gave loans to large firms with implicit government guarantees or cross-debt guarantees, as discussed earlier. Moreover, the linkage between chaebols and financial institutions exacerbated the problems. According to Kim (1999), chaebol with nonbank financial institutions show a high debt-equity ratio while those chaebol-controlled financial institutions show a lower ROA. These results suggest that chaebols were transferring resources from financial institutions to poorly performing industrial firms.

Few Legal Rights or Types of Protection for Minority Shareholders. As equity holders, shareholders have incentives to induce firm management to pursue value maximization. However, effective monitoring activity is underprovided, as it has public-good properties. While a monitoring shareholder pays all costs, he or she cannot monopolize the benefit of monitoring but shares it with other shareholders. When a shareholder overcame free-rider problems associated with the public-good property of monitoring, the shareholder was likely to face difficulty in actively engaging in monitoring because most shareholder rights required a minimum 5 percent ownership that few shareholders had. Shareholders needed at least 5 percent ownership to do any of the following: remove a director, file an injunction, file a derivative suit, demand a convocation, inspect accounting books, inspect corporate affairs and company property, or request a removal of liquidation receiver. Over 97 percent of shareholders lacked these rights as they were small investors with less than 1 percent ownership. Even when small shareholders do not have certain rights, minority shareholders as a group could be better protected when class action suits are introduced and fiduciary duty is imposed on directors and managers. ${ }^{15}$ However, neither class action suits nor fiduciary duty was introduced. Therefore, minority shareholders had few legal rights or types of protection. So they had difficulty preventing controlling shareholders and firm managers from pursuing wasteful projects.

Negligent Board of Directors. Without a significant exit threat and little financial-institution monitoring, internal monitoring and discipline become more important. The board of directors should monitor and discipline managers, thereby mitigating the opportunistic behavior of controlling shareholders. However, boards of directors did not. We have indirect evidence that boards did not represent all the shareholders' interests, and did not monitor controlling shareholders. Before the crisis occurred, over 75 percent of firms polled said that they rarely or never con-

15. See Johnson et al. (2000) for more discussion on fiduciary duty and duty of care for managers and directors. 
Table 5.11 Frequency of Considering Minority Shareholder Opinion in Selecting Directors and Auditors (\%)

\begin{tabular}{lccccc}
\hline Type of Firm & Always & Often & Sometimes & Rarely & Never \\
\hline Owner-manager & 6.2 & 6.2 & 12.5 & 31.3 & 43.8 \\
Hired manager & 2.9 & 5.7 & 14.3 & 40.0 & 37.1 \\
\hline
\end{tabular}

Source: Jun and Gong (1995).

Table 5.12

Outside Directors’ Attendance and Approval Rates (\%)

\begin{tabular}{ccc}
\hline Agenda Approval & Board Attendance & Other Involvement \\
\hline 99.3 & 66.0 & 6.2 \\
\hline
\end{tabular}

Source: Jang (2000).

sidered the minority shareholders' opinion in selecting directors and auditors (Jun and Kong 1995). Because board members were elected through separate majority votes, controlling shareholders were able to elect all directors they recommended. On average, the controlling shareholders could control more than 40 percent of shares in the largest thirty chaebols as they controlled not only their family ownership but also in-group ownership, as shown in table 5.10. Therefore, the controlling shareholders were able to select all directors and, hence, have all the control (see table 5.11).

Moreover, once directors and auditors were elected, they did not have to represent the firm value or shareholder groups' interest. The legal responsibilities of directors are based on the principle of duty of care. ${ }^{16}$ Under this principle, directors are given the benefit of the doubt when conflicts of interest are in question. Otherwise, their willfulness or negligence is to be proved legally. Consequently, board members were accountable only to the controlling shareholders, as small shareholders with less than 5 percent of ownership could not remove them. The extremely high agenda approval rate of outside directors after the crisis (see table 5.12) implies that directors did not hinder controlling shareholders from pursuing private benefits.

Inadequate Financial Information. Inadequate financial information hinders management evaluation, thereby obstructing rewards for good managers and removal of poor managers. The market lacked accurate and reliable information on firm performance and management due to low accounting standards, lack of transparency, and government-triggered incentives for firms to exaggerate their size. Accounting standards in Korea 
Table 5.13

Review of Auditing Firms' Financial Statements, 1998-2000

\begin{tabular}{lccc}
\hline & Firms (A) & Improper Auditing (B) & Ratio (B/A) \\
\hline Regular auditing (listed firms) & 97 & 29 & $29.9 \%$ \\
Irregular/frequent auditing & 6 & 3 & $50 \%$ \\
Special auditing & 48 & 46 & $96 \%$ \\
Consigned auditing & 118 & 116 & $98 \%$ \\
Total & 269 & 194 & $72 \%$ \\
\hline
\end{tabular}

Source: Financial Supervisory Service (2000).

Table 5.14 Large Chaebol under Insolvency Procedures, As of August 1999

\begin{tabular}{lccccccccc}
\hline & Daewoo & Donga & Halla & Kohap & Jinro & Anam & Haitai & Kangwon & Shinho \\
\hline Type & w/o & w/o & r/o & w/o & c/o & w/o & c/o & w/o & w/o \\
Rank in 1996 & 2 & 11 & 17 & 18 & 22 & 23 & 24 & 26 & 29 \\
\hline
\end{tabular}

Source: Ministry of Finance and Economy (1999).

Notes: $\mathrm{w} / \mathrm{o}=$ workout $; \mathrm{r} / \mathrm{o}=$ reorganization; $\mathrm{c} / \mathrm{o}=$ composition .

did not meet accepted international standards, so poor auditing hindered efforts to monitor and evaluate firm performance. For example, when firm A guarantees debt payment to firm B, A need not report such action accurately, thereby hiding A's higher risk. Furthermore, with easy access to debt financing, chaebols need not attract and retain equity investors through financial transparency. Indeed, withholding information from other shareholders facilitates firm control by the dominant shareholder.

It is difficult to measure how opaque the financial statements were before the crisis. However, recent auditing of financial statements by the Financial Supervisory Service reveals many flaws. On average, the review found that 72 percent of audits had flaws. Improper auditing ranges from minor errors to fraud. So firm financial statements in earlier years facing less scrutiny were likely more flawed and misleading (see table 5.13).

\subsection{Effects of Recent Corporate Governance Reforms}

\subsubsection{Major Changes}

Since the crisis occurred, several measures have been introduced to improve the corporate governance system, including more credible exit threats for large firms, strengthened minority shareholders' rights, mandated outside directors, and increased roles for boards of directors.

Many large conglomerates, including Daewoo, which was ranked second in 1999, have fallen to insolvency procedures (see table 5.14). Although the government continues to try to rescue some chaebols (e.g., 
Table 5.15

M\&A Trends before and after the Crisis

\begin{tabular}{lccc}
\hline & $\begin{array}{c}\text { Total } \\
\text { Cases }\end{array}$ & $\begin{array}{c}\text { Cases by } \\
\text { Foreigners }\end{array}$ & $\begin{array}{c}\text { Amount by Foreigners } \\
\text { (\$ billions) }\end{array}$ \\
\hline 1997 & 418 & 19 & 0.84 \\
1999 & 557 & 168 & 8.80 \\
Change & 139 & 149 & 7.86 \\
& $(33.2 \%)$ & $(784 \%)$ & $(935 \%)$ \\
\hline
\end{tabular}

Source: Korea Fair Trade Commission $(1998,2000)$.

Table 5.16

Key Items of Minority Shareholders' Rights (\%)

\begin{tabular}{lccc}
\hline & $\begin{array}{c}\text { Former } \\
\text { Commercial Code }\end{array}$ & Amendments & $\begin{array}{c}\text { Securities and } \\
\text { Exchange Act }\end{array}$ \\
\hline Requesting removal of a director & 5 & 3 & 0.5 \\
Right to injunction & 5 & 1 & $(0.25)$ \\
& 5 & 1 & 0.5 \\
Derivative suit & n.a. & 3 & 0.01 \\
Shareholder's proposal & 5 & 3 & 1 \\
Demand for convocation & 5 & 3 & $(0.5)$ \\
Inspect account books & 5 & 3 & $(1.5)$ \\
& & & 1 \\
Inspect affairs and property & 5 & 3 & $(0.5)$ \\
Request a new liquidation receiver & & & $(1.5)$ \\
& & & 0.5 \\
& & & $(0.25)$ \\
\hline
\end{tabular}

Source: Joh (2001; original source, Ministry of Finance and Economy).

Notes: n.a. $=$ not applicable. Appraisal rights of general shareholders' meeting convocation and shareholder proposals estimated on the basis of voting stocks. Numbers in parentheses show cases of corporations with more than 100 billion won in paid-in capital at the end of the most recent business year.

Hyundai), these failures signal a new government policy of nonintervention in the corporate sector. So many failing chaebols were losing so much money that the government may have lacked the funds to save them from bankruptcy.

In addition, all M\&As, including hostile takeovers and foreign takeovers, have been legalized. Compared to 1997, the number and amount of M\&As, especially by foreign firms, had skyrocketed in 1999 (see table 5.15). In short, large, failing firms face more credible exit threats than before.

The government has lowered the minimum shareholding requirements for many shareholder rights (see table 5.16). Now any shareholder with 0.01 percent of firm ownership can file a derivative suit. Despite such changes, monitoring by individual small shareholders remains unlikely, 
Selection of Outside Directors

\begin{tabular}{lcccc}
\hline & \multicolumn{4}{c}{ Recommending Party } \\
\cline { 2 - 5 } & Controlling Shareholder & Main Creditor & Employee & Others \\
\hline Ratio & 343 & 25 & 20 & 77 \\
& $(73.8 \%)$ & $(5.3 \%)$ & $(4.3 \%)$ & $(16.6 \%)$ \\
\hline
\end{tabular}

Source: Jang (2000).

Table 5.18

Directors' Attendance Rate Classified by Agenda Category (\%)

\begin{tabular}{cccc}
\hline $\begin{array}{c}\text { Immediate Public } \\
\text { Disclosure }\end{array}$ & $\begin{array}{c}\text { One-Day } \\
\text { Disclosure }\end{array}$ & $\begin{array}{c}\text { Transactions with } \\
\text { Controlling Shareholders }\end{array}$ & Others \\
\hline 61.4 & 52.7 & 36.6 & 47.5 \\
\hline
\end{tabular}

Source: Jang (2000).

mostly due to the free-rider problems associated with the public-good property of monitoring.

Now, after the crisis, outside directors are mandated, and their role has been strengthened. But the situation has not changed much. In 1999, more than 73 percent of board members selected were recommended by the controlling shareholders (see table 5.17). Moreover, the overall activity of directors is disappointing. As discussed earlier, their agenda approval rate is very high, exceeding 99 percent. Further, when the boards have to approve transactions involving controlling shareholders, the attendance rate is very low (see table 5.18). In short, the oversight role of boards of directors is still limited.

\subsubsection{Effects of Reform}

It is too early to evaluate the full effects of corporate governance reforms on the corporate sector. Nevertheless, some of the early results imply changes in the corporate sector. Joh (2002) argues that the corporate sector shows improved profitability in 1999 and 2000 compared with the precrisis periods. In particular, surviving chaebols show higher profitability.

Chiu and Joh (2003) try to evaluate how the crisis and corporate reform affect the structure of chaebols. They argue that a firm's rate of return depends on market risk, firm idiosyncratic risk, and group risk. Through an internal capital market, chaebol structure enables firms to transfer idiosyncratic risks to other firms and exposes them to other firms' risks as well. Facing transferred risk and common group risk, chaebol-affiliated firms show synchronicity in their stock market rates of return. Using the daily stock market data between 1996 and 2001, Chiu and Joh measure the strength of business group structure through risk transfer and synchronicity. The risk transfer of small chaebols has increased compared to the pre- 
crisis period. However, the risk transfer of large chaebols has decreased below the precrisis level during the crisis and post-Daewoo-collapse periods (Daewoo was second-largest chaebol in 1999). While the level of synchronicity remains above the precrisis level, the synchronicity of large chaebols decreased below the precrisis level. Using firm-level panel data, they show that the effect of group risk is high during the crisis and reform periods. But it becomes smaller than its precrisis level for large chaebols during the post-Daewoo-collapse period.

Joh and Ryoo (2000) examined the extent of a controlling shareholder's private gains. Since they are difficult to detect, the proportional voting rights premium $(P V R P)$ is used. PVRP is the difference in common stock price and preferred stock price divided by the preferred stock price. Common stocks have voting rights and lower dividends. In contrast, preferred stocks have no voting rights but receive higher dividends. Thus, the premium increases during corporate-control contests over a firm (e.g., M\&As) when control rights are sought, or when a shareholder can reap private gains through control-ownership disparity. Otherwise, the PVRP will be smaller. For example, average PVRPs in the United States, Sweden, and the United Kingdom are 5.3 percent, 6.5 percent, and 13.3 percent, respectively.

In contrast, the PVRP in Korea has been very large with wide fluctuations. The average PVRP was around 95 percent of a common share in 1996. Because takeover threats were almost nonexistent due to legal constraints, the premium before the crisis mostly represents private benefits. The average PVRP in 1999 after restructuring was lower than in 1996, but still around 81 percent. In contrast, this result suggests that investors believe controlling shareholders' private gains are still high, but smaller than before the crisis.

\subsection{Conclusion}

High debt-equity ratios, low long-term firm profitability, and weak corporate governance helped cause Korea's 1997 economic crisis. High debtequity ratios stemmed from government policy, firms' inflation of their reported size, and negligent bank lending. Government industrial policy pushed development of specific industries and gave special incentives to large firms. Firms then inflated their apparent size through cross-holdings and cross-debt guarantees. Moreover, government-directed banks continued lending money to low-profitability firms. As a result, many large firms had huge debt-equity ratios.

Low firm profits were caused partially by unprofitable investment in affiliated firms. Control-ownership disparity and chaebol organization correlated with low profitability, suggesting that controlling shareholders ex- 
ploited these unprofitable investments for private gains. Moreover, Korea's weak governance system allowed such low profitability to persist for nearly ten years. Factors that contribute to the failure of corporate governance include the following: (1) no credible exit threat, (2) lack of financialinstitution monitoring, (3) few legal rights or types of protection for minority shareholders, (4) negligent boards of directors, and (5) inadequate financial information.

After maintaining high debts and low profitability for a long time, the Korean corporate sector experienced massive failures in 1997. Partially prompted by changes in government policies regarding the corporate governance system, including allowing many of the largest chaebols to fail, the corporate sector has been under pressure to change its structure and goals from size maximization to value maximization.

\section{References}

Altman, Edward. 1968. Financial ratios, discriminant analysis, and the prediction of corporate bankruptcy. Journal of Finance 4:589-609.

Bank of Korea. 1997. Financial statement analysis. Seoul: Bank of Korea.

. Various issues. Economic statistics yearbook. Seoul: Bank of Korea.

. Various years. Financial statement analysis. Seoul: Bank of Korea.

Chiu, Ming Ming, and Sung Wook Joh. 2003. The effects of the economic crisis and corporate reform on business groups: Evidence from Korea. Paper presented at the third Asian Corporate Governance Conference. May, Seoul.

Cho, Yoon Je, and Joon Kyung Kim. 1997. Credit policies and the industrialization of Korea: Lessons and strategies. Seoul: Korea Development Institute.

Choi, Sung Noh. 1996, 1997, 1998. The largest thirty chaebols in Korea. Seoul: Free Enterprise Institute.

Chung, Byong Hyou, and Young Shik Yang. 1992. Korean chaebols. Seoul: Korea Development Institute.

Financial Supervisory Service. 2000. Press release on the review of auditing firms' financial statements, 1998-2000. Seoul: Financial Supervisory Service.

. Various issues. Press release on nonperforming loans. Seoul: Financial Supervisory Service.

Hoshi, Takeo, Anil Kashyap, and David Scharfstein. 1991. Corporate structure, liquidity, and investment: Evidence from Japanese industrial groups. Quarterly Journal of Economics 106:33-60.

Jang, Ha Sung. 2000. A study on the effects of the post-crisis corporate reform. Korea University. Mimeograph.

Jensen, Michael, and William Meckling. 1976. Theory of the firm: Managerial behavior, agency costs, and ownership structure. Journal of Financial Economics 3:305-360.

Joh, Sung Wook. 2000. Micro-dynamics of industrial competition: Evidence from Korean manufacturing plants. KDI Policy Study no. 2000-5. Seoul: Korea Development Institute.

2001. The Korean corporate sector: Crisis and reform. In Korea's economic 
prospects: From financial crisis to prosperity, ed. Yul Kwon and William Shepherd, 116-132. Cheltenham, U.K.: Edward Elgar.

2002. Chaebol reform and structural changes in the corporate sector. Paper presented at conference, The Korean Economy: Beyond the Crisis. October, Seoul.

2003. Corporate governance and firm profitability: Evidence from Korea before the economic crisis. Journal of Financial Economics 68:287-322.

Joh, Sung Wook, and Sang Dai Ryoo. 2000. Evaluation of changes in the corporate governance system of Korean chaebols. Paper presented at the twelfth Pacific Asia Free Trade and Development Conference. May, Seoul.

Johnson, Simon, Rafael La Porta, Florencio Lopez de Silanes, and Andrei Shleifer. 2000. Tunneling. American Economic Review Papers and Proceedings 90:22-27.

Jones, Leroy, and Il SaKong. 1980. Government, business, and entrepreneurship in economic development: The Korean case. Cambridge: Harvard University Press.

Jun, In Woo, and Byeong-Ho Gong. 1995. Corporate governance in Korea. Seoul: Korea Economic Research Institute.

Kim, Chung-Yum. 1997. Policymaking on the front lines: Memoirs of a Korean practitioner, 1945-1979. Seoul: Jung-Ang Daily Press.

Kim, Joon Kyung. 1999. Chaebols' ownership of NBFIs and related problems. KDI Economic Outlook 1 (4): 83-94.

Koo, Bonchun. 1998. Reform measures for Korean bankruptcy reorganization and composition. Seoul: Korea Development Institute.

Korea Fair Trade Commission. 1998, 2000. White book for Fair Trade Commission. Seoul: Korea Fair Trade Commission.

1999. Press release on the thirty largest chaebols' ownership structure. Seoul: Korea Fair Trade Commission, April.

- Various dates. Press releases on equity investment and debt payment guarantees of the thirty largest chaebol. Seoul: Korea Fair Trade Commission.

Krueger, Anne, and Jungho Yoo. 2001. Falling profitability, higher borrowing costs, and chaebol finances during the Korean crisis. Paper presented at the Conference on the Korean Crisis and Recovery. 17-19 May, Seoul.

Lee, Byong Ki. 1998. Debt payment guarantees of Korean chaebols. Seoul: Korea Economic Research Institute.

Lee, Chung H. 1992. The government, financial system, and large private enterprises in the economic development of South Korea. World Development 20:187197.

Lee, Soon Woo. 1995. Reorganization of failing firms. Seoul: Jilritamgoo.

Martin, Stephen. 1993. Advanced industrial economics. Oxford, U.K.: Blackwell.

Ministry of Finance and Economy. 1999. Press release on corporate restructuring. Seoul: Ministry of Finance and Economy.

Mossman, Charles, Geoffrey Bell, Mick Swartz, and Harry Turtle. 1998. An empirical comparison of bankruptcy models. Financial Review 33:35-54.

Organization for Economic Cooperation and Development (OECD). 1998. OECD economic surveys. Paris: OECD.

Schumpeter, Joseph A. 1952. History of economic analysis. New York: Oxford University Press.

Shin, Inseok, and Joon-Ho Hahm. 1998. The Korean crisis: Causes and resolution. KDI Working Paper no. 9805. Seoul: Korea Development Institute.

Shleifer, Andrei, and Robert Vishny. 1997. A survey of corporate governance. Journal of Finance 52:737-783.

Takahashi, Kichinosuke, Yukiharu Kurokawa, and Kazunori Watase. 1984. Corporate bankruptcy prediction in Japan. Journal of Banking and Finance 8:229-247. 


\section{Comment Mario B. Lamberte}

Up until the East Asian financial crisis, many observers had admired the rapid growth of the Korean economy. Of course, there were those who doubted the sustainability of Korea's economic growth by comparing its industrial strategy, which relied so much on the chaebols, with that of Taiwan's, which nurtured small and medium enterprises. The criticisms were somewhat muted by Korea's hosting of the summer Olympics and admission to the Organization for Economic Cooperation and Development. In the 1990s, Korea's exports and foreign direct investment to its neighboring countries started to compete with those of Japan's. Korea also started to behave itself like a donor country, at least for Asian countries.

The Korean economy's sterling performance in the last two decades prior to the regional crisis had convinced many that the Korean economic model works and can be applied to their countries. In the Philippines, for example, many (including policymakers) believe that the best way for the country to grow rapidly is to choose a few winning industries, limit the number of large players within each industry, and pour all the necessary government support into those industries. The Philippine president ought to emulate what President Park Chung Hee did to boost exports. Interestingly, the Korean economy's quick recovery from the crisis seemed to have strengthened Philippine resolve to adopt the Korean model. This only goes to show how observers and policymakers in the region have regarded Korea's successful economic model. Indeed, Joh's present paper and her earlier works referred to in that paper are important reading materials for all because they shed light on why the formidable Korean economy collapsed during the East Asian financial crisis.

Joh's main thesis is that the Korean economy's collapse was actually an accident waiting to happen long before the regional financial crisis. The Korean corporate sector, which had been dominated by chaebols, carried very high debt-equity ratios for almost three decades, dwarfing those that can be observed in developed economies. Contrary to expectations, firms' rates of return on equity had been dismally low, and this persisted for a long time. This has made the Korean economy very fragile. A collapse of a few chaebols that had made large contributions to the domestic economy created a ripple effect, causing similarly situated firms to default, and ultimately sending the economy into a tailspin.

Joh's explanations of the causes of the high debt-equity ratios and low performance of the corporate sector certainly deserve greater attention, especially since she backs them up with hard data. She attributes the persist-

Mario B. Lamberte is president of the Philippine Institute for Development Studies. 
ence of high debt-equity ratios to the government's generous incentives and bailout arrangements for large, failing firms; banks' continued lending to highly indebted, poorly performing firms; and very lax rules on firms' cross-holdings and cross-debt guarantees. Controlling shareholders caused the low profitability of firms, which had been sustained because of weak corporate governance, inadequate financial information of firms, failure of banks to act as effective monitors of corporate governance, weak protection systems for minority shareholders, and negligent boards of directors. She has noted some of the recent measures adopted by the Korean government to improve corporate governance, such as instituting more credible exit threats for large firms, mandating outside directors, and increasing roles for boards of directors. It is still too early to evaluate the effectiveness of these measures, but the initial results seem to have been mixed.

As the author noted, the recent crisis is not the first time that the Korean corporate sector encountered a crisis in the last thirty years. There were in fact several crises in the 1970s and the 1980s. Perhaps, the author can elaborate more on what makes the recent crisis different from the previous ones. Is it the extent of participation of foreign investors and lenders, who fled in droves when they saw their interests about to be eroded by the impending crisis? Is it because the same crisis occurred at a time when the political and economic environment could no longer accommodate the solutions used in the past in dealing with similar crises? Or is it the sheer size of the cost of bailing out ailing corporations? It would certainly help if there were information on the costs incurred by the government in bailing out failed corporations in the 1970s and 1980s. The Philippines encountered a severe economic crisis in the mid-1980s. The magnitude of the costs absorbed by the government in cleaning up nonperforming assets of private and government-owned corporations that lent to failed "crony" firms made the public sensitive to any discussion about bailing out another corporation. I wonder if the ailing corporations in the 1970s and 1980s that received substantial assistance from the Korean government in various forms are the same corporations that faced financial distress during the East Asian financial crisis.

One of the things that puzzled me (which, by the way, was partly explained by the author) was the persistently low rate of return on equity despite the high debt-equity ratios of firms. Why would both majority and minority shareholders continue to keep their money in these corporations when "the return on capital had been lower than its opportunity cost"? I am not too familiar with the Korean capital market, but I wonder if the prevailing interest rate on loans has been generally accepted as the indicator of the cost of capital in the country.

Developing countries in the region are keenly watching the progress of Korea's efforts in reforming corporate governance because of the impor- 
tant lessons it brings to them. The trends in mergers and acquisitions are particularly interesting, especially after hostile takeovers and foreign takeovers have been legalized in Korea. However, this is only one part of the story. The other part of the story is whether the corporate sector, in general, and the newly merged or acquired corporations, in particular, have instituted measures to improve corporate governance.

The reforms instituted by Korea in enhancing the rights and protection of minority shareholders are indeed commendable. However, as the author noted, "[d]espite such changes, monitoring by individual small shareholders remains unlikely, mostly due to the free-rider problems associated with the public-good property of monitoring." This is one of the instances in which outside directors can be counted upon. However, the performance of outside directors has so far been generally disappointing. This raises two issues. One pertains to the rules in selecting outside directors. Having outside directors would be rendered futile if controlling shareholders had the unquestioned authority to select them. Even if their role was strengthened, outside directors would still feel beholden to the controlling shareholders. The other issue is the limited market of outside directors in developing economies. I wonder if, in the case of Korea, the corporation code allows foreigners to sit as outside directors, at least in big corporations, to make up for the lack of such capacity at home. I would hasten to add, however, that the monitoring system being developed in Korea to assess performance of outside directors is something that could be emulated by other countries in the region that have mandated the inclusion of outside directors.

Finally, I would like to raise two minor points. One is that it would greatly help the reader to interpret table 5.5 if the author explained how the variable "ownership" is measured and whether the variable "chaebol dummy" refers to the holding companies or to all of the 552 corporations identified as belonging to chaebols. The other is that the author should have briefly discussed the method used in estimating the parameters of the same table.

\section{Comment Philip L. Williams}

\section{The Paper}

Economists, as a profession, are notoriously cynical. We tend to analyze the behavior of individuals and groups by attributing to them the basest of 
motives. Our analysis repeats, with interest, the Christian doctrine of original sin.

The cynicism of the economist is perhaps most pronounced among those of us who devote our professional careers to the analysis of public policy; and this cynicism is constant across time and space. For the past three centuries and across all continents, economists have expressed this cynicism (with very little adaptation to allow for differences in institutions or culture).

This paper, by Sung Wook Joh, is very much in this tradition of extreme cynicism toward government policy. It presents a picture of government policy prior to the currency crisis that is truly alarming. The crisis in Korea is shown to be far more fundamental than a flight of capital caused by foreign providers of funds. Rather, the large Korean conglomerates (the chaebols) were starting to fail some years prior to the currency crisis, but the weakness of these conglomerates was hidden for many years by the government's pressuring the banks to keep lending.

The paper ends on a note of cautious optimism. Recent reforms (allowing conglomerates to fail, legalizing mergers and acquisitions, increasing rights to small shareholders) are worthwhile improvements in corporate governance; but, as always, more remains to be done.

Although the matters rehearsed in the preceding section are the themes of the paper, its chief contribution lies in its detailed empirical analysis. This gives rise to two reflections.

\section{The Korean Enterprise}

The first reflection is stimulated by "Causes of Low Firm Performance," in section 5.2.2, and, in particular, by table 5.7. Table 5.7 suggests that (despite the behavior of government in ensuring the conglomerates get their share of soft loans), Korea has a high rate of turnover of plants. The paper comments that this rate of turnover is much higher for smaller plants than for larger plants.

These observations immediately raise the question of how to map from data relating to plants to data relating to enterprises and, indeed, whether Korean data relating to enterprises are available. Indeed, there is a prior, and much more intractable, issue: where to draw the boundaries to an enterprise if separate legal entities are linked together by intragroup transactions, cross-ownership of shares, common directors, and cross-guarantees of debt.

\section{Rate of Return on Shareholders' Funds}

My second reflection is stimulated by a number of observations in the paper about rates of return on equity compared with rates of return on debt. The paper states (section 5.1 and section 5.2.2) that high debt-equity 
ratios would lead one to expect high rates of return on equity. This makes good intuitive sense: If one is providing equity funds, the more dollars of debt that are standing ahead of me in the queue, the higher is the risk to me if the corporation is in trouble and so the higher will be my average return ex post.

But the paper presents evidence that seems to contradict this story: the data presented show that the average rate of return on equity has frequently been below the prevailing rate of interest. This is an obvious puzzle: If a saver has a dollar, why would he or she transfer this to a corporation in the form of equity (lower returns and higher risk) when it could be transferred in the form of debt?

I shall address my remarks to the rate of return on funds, not to the rate of return on sales, which is the dependent variable in the regression reported in table 5.6. I think, subject to what I am about to say, that the regression could be made more relevant to the argument of the paper by re-running it with the dependent variable as the rate of return on shareholders' funds.

My observations are these. In the first place, one must question the data of the rates of return on shareholders' funds. The paper tells of alarming problems with the recording of assets and liabilities in the balance sheets of the various legal entities that make up each chaebol. For example, we are told (in "Causes of Low Firm Performance") that if firm A invests in affiliated firm B, there may be double-counting of the investments so that the sum of the assets of A and B can exceed the total assets of the group. Similarly, we are told (in "Inadequate Financial Information") that debt payment guarantees by a larger corporation to a smaller corporation within a chaebol can increase the amount of aggregate borrowing because the guarantee is not recorded as a liability in the balance sheet of the larger corporation. These problems suggest that any numbers based on accounting data are likely to be extremely suspect.

The second observation that should be made about the comparison of rates of return on equity compared with debt is that, even if the figures in the company accounts can be used as indicative, the recorded rates of interest cannot be used without adjustment because they hide the large subsidies that were provided to debt finance. A recent paper (Krueger and Yoo 2001) attempts to estimate the magnitude of these subsidies.

\section{Implications for Policy}

These reflections on data impel me to question the (admittedly guarded) optimism of the conclusions of the paper. Governance demands the gathering of information and an ability to react to it. This paper argues overwhelmingly that the information available to providers of funds to Korean 
companies is grossly distorted. The chief culprits seem to be two: (1) government-promoted distortions through control of the banks and (2) poor accounting standards.

These two problems seem to be quite fundamental to the issue of corporate governance in Korea. Until they are addressed, investors will continue to treat Korean corporations with cynicism. Indeed, the cynicism of the investors will match the cynicism of the economists.

\section{Reference}

Krueger, Anne O., and Jungho Yoo. 2001. Chaebol capitalism and the currencyfinancial crisis in Korea. NBER Conference Paper. Cambridge, Mass.: National Bureau of Economic Research, February. 